\title{
MAKNA KEJAHATAN STRUKTURAL KORUPSI DALAM PERSPEKTIF TEORI STRUKTURASI ANTHONY GIDDENS
}

\section{Imadah Thoyyibah}

Sekolah Tinggi Agama Islam Al Kamal, Rembang, Jawa Tengah

Email: imadahthoyyibah80@gmail.com

\section{Abstrak}

Korupsi adalah realitas kejahatan yang tidak lepas dari struktur dan agensi manusia. Perspektif teori strukturasi menekankan adanya relasi dualitas antara agen dan struktur. Struktur meliputi aturan-aturan dan sumberdaya-sumberdaya, serta sistem sosial yang dimobilisasi dalam ruang-waktu oleh agenagen sosial. Korupsi sebagai kejahatan struktural melibatkan struktur mikro dan struktur makro. Pertama, korupsi merupakan kejahatan yang terjadi akibat banalitas (pembiaran/pembiasaan) yang motifnya adalah keserakahan, ketidakjujuran, kesombongan, kepicikan, kedangkalan berpikir dan kepuasan yang sifatnya subjektif. Motif-motif ini terbungkus dalam sistem produksi dan reproduksi aktivitas sosial yang bersifat dialektik. Kedua, korupsi ditopang oleh kondisi modernitas yang mengglobal akibat peristiwa; perentangan ruangwaktu, perkembangan mekanisme pencabutan/ketaktersimpanan lokalitas konteks, dan perkembangan refleksivitas pengetahuan. Agen-agennya adalah mereka yang memiliki nilai intervensi (efek) terhadap suatu tindakan yang korup. Berbagai upaya pembenaran terhadap tindakan korupsi merupakan bentuk rasionalisasi tindakan oleh agen manusia sebagai makhluk kreatif dan refleksif. Motifnya adalah untuk menghindari tanggung jawab moral dan hukum sosial. Perubahan sosial yang bisa dilakukan adalah dengan 'derutinisasi' struktur atau mengambil jarak dengan pengawasan refleksif dari struktur yang mengekang sekaligus memberdayakan benih-benih korupsi yang melibatkan struktur signifikasi, dominasi, dan legitimasi dalam konstitusi-konstitusi sosial.

Kata Kunci:korupsi, kejahatan sruktural, struktur, agensi, strukturasi.

\section{Abstract}

Corruption is the reality of crime that can not be separated from the structure and human agency. The perspective of structuration theory emphasizes the duality relation between agents and structures. The structure includes the rules and resources and the social systems are mobilized in space-time by the social agents. Corruption as a structural crime involving micro structures and macro structures. First, corruption is a crime that occurs due to banality 
(omission/habituation) whose motive is greed, dishonesty, arrogance, pettiness, shallowness of thought and the subjective satisfaction. Motifs are encased in a system of production and reproduction of social activity that is dialectic. Secondly, corruption is sustained by the conditions of a globalized modernity as a result of events like the separation of time and spice, the development of disembedding mechanism of localized context, and the reflexive appropriation of knowledge. Agents are those that have a value of intervention (effect) against a corrupt act. Various efforts to justify acts of corruption is a form of rationalization of actions by human agents as creative and reflexive beings. Their motive is to avoid moral responsibility and social law. Social change can be done by 'deroutinization' of structure or distancing by reflexive monitoring of structure while constraining and enabling the seeds of corruption that involves the structure of signification, domination, and legitimation in the constitutions of society.

Keywords: corruption, structural crime, structure, agency, structuration.

\section{PENDAHULUAN}

Perilaku korupsi suatu negara di era globalisasi dan pasar bebas saat ini, turut menentukan nasib perekonomian bangsanya. Indonesia yang disebut-sebut sebagai salah satu bintang negara emerging markets ternyata merupakan negara terkorup dari 16 negara tujuan investasi di Asia Pasifik (Kompas.com, Senin 8/3/2010). Hasil ini berdasarkan survei pelaku bisnis oleh perusahaan konsultan Political \& Economic Risk Consultancy (PERC) yang berbasis di Hong Kong (Vivanews, 8 Maret 2010).

Hal yang menarik, kenaikan indeks prestasi korupsi Indonesia ini dibarengi dengan semakin banyak terkuaknya kasus korupsi yang ditangani Komisi Pemberantasan Korupsi (KPK) dan aparat penegak hukum seperti kasus Bank Century, mafia pajak, mafia hukum dan lain-lain. Perjalanan pemerintah Indonesia dalam memberantas korupsi selama periode kedua Presiden SBY (Susilo Bambang Yudhoyono) rupanya tidak sepenuhnya berjalan mulus. Kasus kriminalisasi anggota KPK, mafia pajak, dan mafia hukum pun justru berkembang menjadi 'politisasi isu' yang mengarah pada pemakzulan presiden; dengan kata lain semakin sulit pula untuk membuka jaringan mafia korupsi di 
Indonesia yang sudah multidimensional dan melibatkan jaringan beberapa penguasa dan birokrat.

Soemardjan sebagaimana dikutip oleh Parwadi (2007:58) menyatakan bahwa korupsi itu ibarat 'pelacuran'. Siapapun yang terlibat, apakah pihak yang langsung melakukan korupsi atau penikmat, samasama mendapatkan bagian hasil korupsi. Lain halnya dengan Parwadi yang mengatakan korupsi tak ubahnya seperti 'candu' dan pelakunya seperti 'pecandu' pengguna obat-obatan terlarang, sekali korupsi mereka akan ketagihan untuk mengulanginya dan mengulanginya lagi.

Korupsi tidak pernah dapat dilepaskan dari interaksi kekuasaan. Sebagaimana dikatakan Arendt (1993: 302), para politikus yang masih bermental animal laborans dimana orientasi kebutuhan hidup dan obsesi akan konsumsi masih mendominasi, cenderung menjadikan politik sebagai mata pencaharian utama. Akibatnya, korupsi pun tidak terelakkan lagi.

Alkostar dalam bukunya Korupsi Politik di Negara Modern (2008: 381) mengatakan bahwa ideologi hukum yang menegasikan kontrol sosial politik dari rakyat berpeluang terjadinya penyalahgunaan wewenang atau korupsi kekuasaan. Proses feodalisasi hukum pada masa Orde Baru misalnya telah menjadikan korupsi semakin merajalela. Hukum dibuat untuk kepentingan penguasa dan menjadikan penjahat sesungguhnya menjadi kebal hukum.

Siswanto (2008: 294) berpendapat, seorang koruptor pada hakikatnya adalah orang yang sedang mengalami proses 'alienasi' oleh dirinya sendiri karena 'keserakahan' dan ketidakmampuan mengendalikan diri atas kehendak yang tanpa batas untuk memenuhi hawa nafsu rakus-keduniawian. Oleh karena itu, korupsi dikategorikan sebagai kejahatan kemanusiaan dan tindakannya adalah bagian dari kejahatan moral.

Korupsi dalam ilmu-ilmu sosial biasa disebut sebagai kejahatan struktural namun struktur di sini dimaknai sebagai sesuatu yang mengekang di luar kuasa sang agen. Sebagai kejahatan struktural, pelaku tidak merasa melakukan tindak kejahatan karena struktur yang mem- 
biarkan atau mengamini (Siswanto, 2008: 120). Lantas apa sebenarnya struktur itu? bagaimana struktur itu dimaknai dan disadari oleh pelaku kejahatan?

Korupsi sebagai kejahatan struktural dipandang oleh sebagian kalangan sebagai akibat langsung dari politik kekuasaan. 'Kekuasaan' seringkali didefinisikan berdasarkan tujuan dan kemauan, yakni sebagai kemampuan mencapai hasil-hasil yang diinginkan dan dimaksudkan. Sebaliknya Parsons (1971) dan Foucault (1979) misalnya, sebagaimana dikemukakan oleh Giddens (1984: 15), memandang 'kekuasaan' sebagai milik masyarakat atau komunitas sosial. Hal ini mencerminkan dualisme antara subjek dan objek, antara agen dan struktur. 'Kekuasaan' dalam agensi menurut Giddens (1984: 14) berarti kemampuan bertindak sebaliknya atau mampu melakukan campur tangan di dunia atau menarik intervesi itu, dengan efek mempengaruhi proses atau keadaan khusus secara sadar maupun tidak.

Korupsi sebagai kejahatan struktural melibatkan sarana material salah satunya adalah uang. Konsepsi Giddens dijelaskan, uang merupakan alat perentangan waktu dan ruang. Uang merupakan alat simbolis atau sarana pertukaran yang bisa diedarkan terlepas dari siapa atau kelompok mana yang memegangnya pada waktu dan tempat tertentu. Ekonomi uang (money economy) telah menjadi sedemikian abstrak dalam kondisi dewasa ini. "Money bracket time and space" (Giddens, 1991:18).

Sistem ahli yang berisi kemampuan profesional menjadi prasarana pengorganisasian bidang-bidang material (uang) dan tindakan sosial. Praktik deposito misalnya, sudah melibatkan konsep investasi dan suku-suku bunga yang menjadi objek kajian ilmu ekonomi keuangan. Praktik deposito, oleh sosial dilakukan atas dasar motivasi, kepentingan, keterbatasan, dan maksud dari agen-agen kongkret; seperti untuk menabung, untuk keamanan, untuk mendapatkan hadiah dan lainlain. Praktik sosial perbankan yang terkait sistem ahli teknologi dan komunikasi juga memunculkan cara-cara baru kejahatan korupsi seperti money laundry. Tindakan tersebut akibat dari proses hermeneutika ganda (double hermeneutic), yaitu "arus timbal balik antara dunia sosial 
yang diperbuat oleh khalayak dan wacana ilmiah yang dilakukan oleh ilmuwan sosial" (Giddens, 1984: 374, 1976: 86).

Masyarakat sosial biasa mengkaitkan adanya kejahatan dengan tindakan seseorang. Pada level ini, ada pengandaian antropologis manusia dari kejahatan struktural yang layak ditelusuri, yakni manusia sebagai makhluk yang memiliki kehendak, konteks atau situasi, dan tujuan atau hasil di dalam hidupnya; dengan demikian apa kaitan pengandaian antropologis tersebut dengan terciptanya kejahatan struktural?

Menurut Giddens (2003: 21) struktur adalah rules and resources (aturan-aturan dan sumberdaya-sumberdaya) yang bisa disendirikan dan menghasilkan risiko yang jelas, yakni kesalahan interpretasi. Struktur dapat dikatakan ada di berbagai sendi kehidupan masyarakat; seperti ilmu pengetahuan, wacana, budaya, tradisi, dan ideologi. Struktur terbentuk atau melekat dalam tindakan. Struktur merupakan 'pedoman' yang dapat merentang dalam ruang dan waktu menjadi prinsip-prinsip sang agen untuk melakukan suatu tindakan (seperti kejahatan).

Struktur lambat laun akan menjadi sistem dalam kehidupan jika berulang dan teregulasi atau terlegitimasi oleh gugusan struktur yang akhirnya menjadi sistem budaya yang tidak dipertanyakan lagi. Nilainilai yang sudah mapan dalam kondisi ini akan tergerus seiring dengan proses strukturasi yang berulang dalam kehidupan masyarakat. Daya kritis akan melemah dan tergantikan dengan struktur-struktur yang melembaga akibat 'kesadaran praktis' (Priyono, 2002: 28-29).

Pandangan Giddens (1984: 13) tentang penyebab tindakan kejahatan, menurutnya dapat dianalisis melalui akumulasi-akumulasi peristiwa yang berasal dari keadaan pemicu yang tanpa keadaan ini tidak akan bisa ditemukan akumulasi tersebut. Keadaan tersebut dapat dipahami dalam logika strukturasi, yakni penataan relasi-relasi sosial lintas ruang dan waktu berdasarkan dualitas struktur.

\section{TEORI STRUKTURASI ANTHONY GIDDENS}

Teori strukturasi bermula dari kritik Giddens terhadap cara kerja 
strukturalisme, post-strukturalisme dan fungsionalisme dalam melihat struktur. Salah satunya adalah, apa yang dilakukan oleh tokoh strukturalis Claude Levi Strauss telah berimplikasi jauh terhadap terapan analisis ilmu-ilmu sosial. Giddens mengkritik perspektif strukturalis merupakan "penolakan yang penuh skandal terhadap subjek". Sebagai contoh dalam memahami gejala dalam masyarakat kapitalis, perhatian strukturalis tidak terpusat pada perilaku para pemodal atau konsumen, tetapi justru pada logika-internal kinerja modal; dengan kata lain, strukturalisme adalah bentuk dualisme (Giddens, 2008: 335).

Dualisme ini juga ada pada perspektif post-strukturalis (Giddens, 1987:348). Pemikir penting post-strukturalis, Jasques Derrida misalnya, melihat perbedaan bukan hanya menunjuk sesuatu, melainkan sebagai pembentuk identitas yang bahkan merupakan hakikat sesuatu tersebut; atau dualisme yang ada pada fungsionalisme Talcott Parsons. Fungsionalisme merupakan cara berpikir yang mengklaim bahwa sistem sosial punya kebutuhan yang harus dipenuhi. Bagi Giddens, sistem sosial tidak punya kebutuhan apapun, yang punya kebutuhan adalah para pelaku. Fungsionalisme memberangus fakta bahwa manusia sebagai pelaku, bukan orang-orang dungu, dan bukan robot yang bertindak berdasar "naskah" (peran yang sudah ditentukan). Fungsionalisme menafikan dimensi ruang dan waktu dalam menjelaskan gejala sosial, akibatnya terjadi pertentangan antara yang 'statis' dan 'dinamis', atau antara 'stabilitas' dan 'perubahan'. Pada intinya teori strukturasi menekankan kembali pada prioritas logis dari struktur (Priyono, 2002: 10).

Anggapan struktur sebagai "batasan" bagi perilaku tidak lebih merupakan strategi alternatif yang dipergunakan para praktisi dalam usahanya memberikan rasionalitas teoritis. Para sosiologi interpretatif dan fenomenologis melihat permasalahan batasan ini terfokus pada 'prosedur' yang dipergunakan oleh aktor-aktor sosial dalam usaha menghasilkan dunia yang terstruktur. Struktur sosial tidak memiliki eksistensi yang riil kecuali dalam benak para pelaku yang memberinya arti. Sudut pandang ini menunjukkan penjelasan struktural hanya akan memiliki validitas sejauh hal itu dialami secara subjektif. Struktur 
dengan demikian adalah sesuatu yang dikatakan oleh para pelakunya. Apabila struktur mempengaruhi praktik, maka hal ini terjadi karena struktur dipandang memiliki semacam realitas, tetapi sebuah realita yang tergantung pada "konstruksi" individual (Giddens, 1984: Bab I).

Teori strukturasi bermaksud untuk mempermudah melihat dunia yang terstruktur dengan mengedepankan konsep agensi manusia. Caranya adalah dengan mengenali perbedaan antara konsep 'struktur' dengan 'sistem'. Sistem sosial tidak memiliki struktur namun memperlihatkan 'sifat-sifat struktural'. Sifat-sifat struktural ini hanya muncul di dalam berbagai tindakan instant serta menjadi jejak-jejak memori yang memberi petunjuk akan agen-agen manusia yang telah banyak memiliki pengetahuan (Giddens, 1984: 25). Sifat-sifat struktural yang muncul dalam sebuah totalitas reproduksi sosial, oleh Giddens disebut sebagai prinsip-prinsip struktural (structural principles). Praktik-praktik sosial yang memiliki perluasan ruang dan waktu terbesar dalam totalitas disebut sebagai 'institusi' (institution) (Giddens, 1984: 16-17).

Strukturasi adalah kondisi untuk menjelaskan bagaimana sebuah tatanan relasi-relasi sosial terstruktur dalam hubungan dualitas (timbal balik) antara sang pelaku dengan struktur (Ross dalam Beilharz, 2002: 22-23). Hubungan dualitas struktur dalam reproduksi sosial dapat dipahami dengan adanya tiga tingkatan kesadaran atau tiga dimensi internal dalam diri manusia, yaitu; kesadaran diskursif, kesadaran praktis, dan kognisi/motivasi tak sadar. Giddens menawarkan konsep-konsep ini sebagai pengganti triad psikoanalitis Sigmund Freud yakni ego, super-ego, dan id (Giddens, 1984: 7).

'Motivasi tak sadar' mengacu pada keinginan atau kebutuhan manusia yang berpotensi mengarahkan tindakan, tetapi bukan tindakan itu sendiri. 'Kesadaran diskursif' mengacu pada pengetahuan tindakan manusia yang bisa direfleksikan dan dijelaskan secara rinci serta eksplisit. Adapun 'kesadaran praktis' ialah pengetahuan tindakan manusia yang tidak selalu bisa diurai atau dipertanyakan kembali. Fenomenologi melihat wilayah ini masuk pada gugus pengetahuan yang sudah diandaikan (taken for granted knowledge) dan merupakan sumber 'rasa aman ontologis' (Ontological security). Keamanan ontologis ialah 
kepercayaan atau keyakinan bahwa alam dan sosial itu kondisinya seperti yang tampak, termasuk parameter eksistensial dasar diri dan identitas sosial (Giddens, 1984:375).

Kesadaran praktis ini merupakan kunci untuk memahami bagaimana berbagai tindakan dan praktik sosial masyarakat lambat laun menjadi struktur, dan bagaimana struktur itu mengekang serta memampukan tindakan/praktik sosial masyarakat. Giddens menyebut tindakan dan praktik sosial itu sebagai 'dunia yang sudah ditafisirkan' (Giddens, 1976: 166). Reproduksi sosial berlangsung lewat keterulangan praktik sosial yang jarang dipertanyakan lagi.

Sebagai sebuah aturan dan sumberdaya, struktur memiliki tiga gugus dimensi yaitu: Pertama, struktur penandaan (signification) yang menyangkut skemata simbolik, pemaknaan, penyebutan, dan wacana. Kedua, struktur penguasaan atau dominasi (domination) yang mencakup skemata penguasaan atas orang (politik) dan barang/hal (ekonomi). Ketiga, struktur pembenaran atau legitimasi (legitimation) yang menyangkut skemata peraturan normatif, yang terungkap dalam tata hukum (Giddens, 1984: 29).

Pertama; bahwa untuk melakukan komunikasi, seseorang membutuhkan sistem tanda dan bingkai interpretasi (tata simbol, wacana/ lembaga bahasa), sehingga struktur signifikasi itu ada. Aktor-aktor sosial, dalam perilaku kehidupan sehari-harinya, secara aktif menghasilkan makna dalam tataran yang telah mereka beri makna; secara bersamaan mereka dipengaruhi oleh cara dimana makna-makna tersebut telah menjadi dirutinkan dan direproduksi. Hal yang dilakukan dan dikatakan masyarakat memiliki konsekuensi bagi struktur sosial. Individu-individu menggerakkan sumber daya, ketrampilan dan pengetahuan yang telah didapatkan dari interaksi sebelumnya.

Praktik-praktik struktur sosial, sebagian selalu berakar pada pertemuan tatap muka, tetapi perjumpaan ini tidak pernah terjadi dalam ruang hampa yang tidak berstruktur, dunia sosial ditengahi dan dipengaruhi oleh sumber daya yang telah memiliki signifikasi sosial dan budaya. Struktur adalah 'proses dialektika' dimana hal yang dilakukan oleh individu adalah juga hal yang mereka bangun. Inilah essensi dari 
strukturasi. Strukturasi juga melibatkan interfusion (penggabungan) konsekuensi yang diharapkan ataupun yang tidak diharapkan, hal yang dimaui dan dilakukan agen bisa menghasilkan konsolidasi atas apa yang tidak diinginkan agen. Gagasan inilah yang menunjukkan bahwa struktur adalah sumberdaya yang memberdayakan sekaligus membatasi masyarakat.

Kedua; untuk mendapatkan atau mempraktikkan kekuasaan, seseorang membutuhkan mobilisasi dua struktur dominasi sebagai fasilitas. Pada dimensi penguasaan, fasilitas ini terdiri dari sumberdaya alokatif (ekonomi) dan otoritatif (politik). Sumberdaya alokatif mengacu pada kemampuan-kemampuan atau bentuk-bentuk kapasitas transformatif yang memberikan komando atas barang-barang, objekobjek atau fenomena material. Adapun sumberdaya otoritatif mengacu pada jenis-jenis kapasitas transformatif yang menghasilkan perintah atas orang-orang atau aktor-aktor.

Istilah 'kekuasaan' harus dibedakan dengan istilah dominasi. Dominasi mengacu pada asimetri hubungan pada dataran struktur, sedang kekuasaan menyangkut kapasitas yang terlibat dalam hubungan sosial pada dataran pelaku (interaksi sosial). Karena itu kekuasaan selalu menyangkut kapasitas transformatif, sebagaimana tidak ada struktur tanpa pelaku, begitu pula tidak ada struktur dominasi tanpa relasi kekuasaan yang berlangsung diantara pelaku yang kongkret. Kekuasaan terbentuk dalam dan melalui reproduksi dua struktur/ sumberdaya dominasi (alokatif dan otoritatif). Meski demikian, menurut Giddens tidak pernah mungkin terjadi penguasaan total atas orang entah dalam sistem totaliter, otoriter, ataupun penjara karena adanya dialektika kontrol (the dialectic of control). Artinya dalam penguasaan selalu terlibat relasi otonomi dan ketergantungan, baik pada yang menguasai maupun pada yang dikuasai sekalipun dalam kadar yang minimal.

Ketiga; untuk memberlakukan sebuah sanksi, orang membutuhkan sarana legitimasi berupa norma atau peraturan (tata hukum/lembaga hukum). Aspek legal (normatif) dibutuhkan untuk memberikan rasa aman (ontological security) dan keabsahan atas interaksi yang dila- 
kukan oleh agen-agen sosial. Perubahan sosial tidak bisa ditempuh dengan kontradiksi sistem, tetapi perubahan dapat ditempuh melalui koordinasi praktik yang dilembagakan dalam sistem dan struktur sosial yang mengatasi ruang dan waktu. Perubahan sosial dalam dimensi ketiga gugus strukturasi hanya bisa dirubah melalui 'derutinisasi' dalam kapasitas 'monitoring refleksif atau mengambil jarak terhadap unsurunsur yang melingkupinya baik secara personal maupun institusional (Giddens, 1984: 7).

\section{MAKNA KEJAHATAN KORUPSI}

Dunia dalam dua dekade terakhir mulai memandang korupsi sebagai isu penting. Fakta ini terlihat dari hasil catatan Konferensi Internasional Anti Korupsi (International Anti Corruption Conference I-X) oleh PBB yang telah dilaksanakan di Washington (1983), New York (1985), Hongkong (1987), Amsterdam (1992), Sydney (1980), CancunMexico (1993), Beijing (1995), Lima-Peru (1997), Durban (1999), dan Praha (2001). Hasil dari konferensi tersebut disepakati bahwa masalah korupsi bukan saja masalah negara-negara tertentu saja tetapi juga merupakan masalah dunia (Singgih, 2002: iii); bahkan hasil Konvensi Internasional PBB tanggal 7 Oktober 2003 di Wina menetapkan 'corruption' sebagai 'kejahatan luar biasa' atau extra ordinary crime (Nurdjana, 2010: 44).

Kejahatan dalam bahasa Inggris dikenal dengan istilah evil atau crime. Bedanya evil merupakan kejahatan yang terjadi akibat unsur kemalangan, sedangkan crime lebih kepada kejahatan yang terjadi akibat unsur kesalahan manusia (Echols dan Shadily, 1996: 155 \& 221). Kejahatan yang disebabkan oleh unsur kesalahan manusia umumnya dibahas dalam studi criminology. Makna kejahatan (crime) dalam konteks kejahatan moral merupakan suatu tindakan-tindakan yang disengaja atau tidak disengaja yang bernilai destruktif seperti menyebabkan penderitaan bagi orang yang baik dan orang yang berdosa (Titus dkk., 1994: 461).

Bria (2008: 21-22) menyebutkan bahwa diskusi mengenai kejahatan (evil) dalam literatur filsafat umumnya dibagi menjadi dua bagian, 
yakni kejahatan moral dan kejahatan alamiah. Kejahatan moral ada dua jenis: evil by commission dan evil by omission. Jenis pertama, berupa kejahatan yang muncul dari seseorang atau beberapa pelaku yang secara sadar dan bebas melakukan tindakan yang salah secara moral, seperti bertindak tidak adil dan tidak jujur (pembunuhan, pemerkosaan, pencurian, dan lain-lain) sehingga menyebabkan penderitaan bagi pihak lain; sedangkan jenis kedua berupa kejahatan dengan membiarkan orang lain menjadi korban kejahatan moral meskipun ia dapat menolongnya. Adapun kejahatan alamiah mengacu pada penderitaan yang muncul dari determinasi alamiah, seperti cacat bawaan, banjir, gempa bumi, tsunami, gunung meletus, dan lain-lain.

Hoefnagels dalam Philosophy of Crime (1984: 12/17) memandang kejahatan adalah persoalan perilaku dan penilaian. Oleh sebab itu, istilah ini sebenarnya terletak pada perbedaan nilai-nilai di berbagai kelompok masyarakat yang berbeda. Suatu masyarakat yang majemuk dengan norma-norma kelompok yang berbeda, tidaklah mungkin untuk mencapai suatu definisi kejahatan yang bersifat universal maupun konsep kejahatan yang meliputi moralitas yang universal pula. Aspekaspek psikologis dan sosiologis sangat berpengaruh dalam merumuskan arti kejahatan.

Secara ilmiah, terdapat tiga konsep kejahatan yang berlaku dalam ilmu-ilmu sosial (Hoefnagels, 1984: 51-52), yaitu: (1) Konsep hukum: kejahatan ialah perilaku yang dapat dijatuhi hukuman. Konsep ini bersifat relatif sehubungan dengan kebudayaan dan pembabakan perkembangan sejarah masyarakat yang bersangkutan; (2) Konsep sosiologi; melihat kejahatan sebagai deviasi perilaku yang asosial, menurut penilaian masyarakat tertentu; (3) Suatu gabungan antara konsep hukum dengan konsep sosiologis. Sebuah definisi yang menggabungkan konsep hukum dan sosiologis tentang kejahatan adalah bahwa kejahatan merupakan perilaku yang dinyatakan sebagai perbuatan yang dapat dihukum (bisa oleh undang-undang atau reaksi sosial).

Dewasa ini, pendekatan kombinasi hukum dan sosiologi menempati posisi penting dalam analisis kejahatan, karena mengkaitkan secara ilmiah mengenai law in the book dan law in action secara serasi. Relatif- 
nya makna kejahatan dan perilakunya memerlukan upaya untuk menyimak lebih mendalam dan mendasar tentang hakikat istilah tersebut di dalam pergaulan hidup manusia, terutama menelusuri hakikat atau makna dari kejahatan korupsi.

Istilah 'kejahatan korupsi' mengarah pada bentuk penilaian afirmatif untuk meyakinkan bahwa korupsi memang menjadi bagian dari kejahatan dan perbuatan tercela dari penyakit masyarakat. Korupsi diidentifikasi sebagai varian kejahatan yang bersifat laten yang potensial merugikan dan membahayakan negara, sebagaimana tindak pidana lainnya yang identik dengan ancaman terhadap rule of law, keadilan dan kemanusiaan (Prakoso dkk. dalam Syamsuddin, 2011:1).

Perspektif para ekonom yang memandang bahwa korupsi dapat mendorong pertumbuhan ekonomi mulai ditinggalkan banyak kalangan. Korupsi dipandang bukan hanya sebagai permasalahan moral, tetapi sebagai permasalahan multidimensional (politik, hukum, ekonomi, sosial, dan budaya). Perubahan cara pandang dan pendekatan terhadap korupsi, yang diikuti menjamurnya kerja sama antarbangsa dalam isu ini menyemai optimisme bahwa perang melawan korupsi adalah perang yang dapat dimenangi oleh semua pihak (Wijayanto dan Zachrie, 2009: 5).

Istilah korupsi pada awalnya berasal dari bahasa Latin yaitu corruptive, corruptus, corruptio= menyuap, penyuapan. Kata ini berasal dari kata corrumpore $=$ merusak (suatu kata Latin tua), dari bahasa Latin inilah kemudian diadaptasi ke bahasa Eropa seperti Inggris: corruption, corrupt; Perancis: corruption; Belanda corruptive atau korruptie (Nurdjana, 2010: 14).

Corrupt dalam bahasa Inggris berarti jahat, buruk (Echols dan Shadily, 1996: 149). Kamus bahasa Indonesia menyebutkan, 'korup' berarti: busuk, buruk; suka menerima uang sogok (memakai kekuasaannya untuk kepentingan sendiri dsb); korupsi': perbuatan yang buruk (seperti penggelapan uang, penerimaan uang, sogok dan lain sebagainya) (Poerwadarminta, 1984: 524). Korupsi dalam Kamus Ilmiah Popular (Partanto: 1994: 375), berarti: kecurangan, penyelewengan/penyalahgunaanjabatan untuk kepentingan diri, pemalsuan. 
Secara historis konsep korupsi merujuk pada tingkah laku politik atau seksual. Kata Latin corruptus menggambarkan perbuatan apa saja yang jahat dan merusak keutuhan. Ada nada moral pada kata tersebut. Kamus Oxford (Hornby, 1974: 193) disebutkan, corrupt = (ofpersons, their actions) immoral; depraved; dishonest (esp. through taking bribes).

Beberapa literatur dapat menjelaskan secara deskriptif saja dari makna korupsi dibanding sebagai makna konseptual. Sebuah definisi korupsi yang banyak dikutip, adalah "tingkah laku yang menyimpang dari tugas-tugas resmi sebuah jabatan negara karena keuntungan status atau uang yang menyangkut pribadi negara karena keuntungan status atau uang yang menyangkut pribadi (perorangan, keluarga dekat, kelompok sendiri); atau melanggar aturan-aturan pelaksanaan beberapa tingkah laku pribadi (Weber dalam Klitgaard, 2005:31).

Weber berpendapat bahwa pandangan masyarakat tentang apa yang disebut 'corrupt' itu berkembang. Sepanjang perjalanan waktu masyarakat lambat laun mampu membuat pembedaan yang lebih tajam antara 'suap' (bribery) dan 'tindakan timbal balik' atau 'transaksi', dan semakin mampu membuat pembedaan-pembedaan ini berlaku dalam praktik. Sekurang-kurangnya ditemukan empat definisi 'suap' yang berbeda dalam setiap zaman suatu masyarakat: "definisi kaum moralis yang lebih maju; definisi hukum sebagaimana tertulis; definisi hukum sejauh ditegakkan; dan definisi praktik yang lazim" (Klitgaard, 2005: 31-32). Definisi kaum moralis menegaskan korupsi pada intinya adalah masalah etika. Ahli hukum John T. Noonan (Klitgaard, 2005: 14) memperlihatkan bahwa, meskipun suap itu sama tuanya dengan pemerintahan, itu bukan karena suap tersebut disetujui dalam kebudayaan-kebudayaan tertentu. Noonan menyimpulkan:

"Suap itu secara universal memalukan. Tak ada satu negeri pun di dunia ini yang tidak memperlakukan suap sebagai tindak kejahatan dalam buku undang-undangnya... Seringkali orang Barat dengan prasangka etnosentrismenya menuduh bahwa sebuah masyarakat modern Asia dan Afrika tidak menganggap tindak penyuapan itu memalukan seperti anggapan orang Barat... Rasa malu dan kemunafikan 
dalam menggunakan bahasa merupakan ujian kejahatan terhadap keutamaan. Rasa malu barangkali terkondisi secara budaya. Rasa malu yang sedemikian kuat dan sedemikian universal itu merupakan pengakuan bahwa ada sesuatu yang pantas dijauhi dalam tingkah laku yang melampaui rasa sekedar tidak sopan dan sekedar tidak legal. Rasa malu tidak secara meyakinkan menentukan; melainkan menunjuk pada segi moral masalah tersebut".

Ilmuwan politik James Q. Wilson pernah menulis, "Masalah korupsi ialah bahwa ia cenderung menjadi persoalan 'Korupsi' dengan huruf besar. Masalah-masalah moral lazimnya mengaburkan masalahmasalah praktis, bahkan dimana pertanyaan moralnya relatif kecil dan masalah praktisnya sangat besar" (Wilson dalam Klitgaard, 2005: 15). Definisi moral saja dengan demikian tidak cukup untuk menjelaskan makna korupsi.

Pada mulanya pemahaman masyarakat tentang korupsi mempergunakan bahan kamus, yang berasal dari bahasa Latin; corruptus yang berarti perbuatan yang tidak baik, buruk, curang, dapat disuap, tidak bermoral, menyimpang dari kesucian, melanggar norma-norma agama, materiil, mental dan melawan hukum. Pengertian tersebut oleh Nurdjana (2010: 16) dipandang sebagai pengertian yang sangat sederhana, yang tidak bisa dijadikan tolak ukur atau standar perbuatan korupsi. Oleh sebab itu, dalam suatu negara atau bangsa dibutuhkan definisi korupsi secara normatif tertulis.

Definisi korupsi yang diusulkan oleh kelompok moralis lebih umum dan mencakup dengan tidak membatasi pada melawan hukum dan merugikan negara saja. Korupsi menurut mereka adalah "tindakan yang bertentangan dengan norma masyarakat, agama, moral, dan hukum dengan tujuan memperkaya diri atau orang lain atau korporasi yang mengakibatkan rusaknya tatanan yang sudah disepakati yang berakibat pada hilangnya hak-hak orang lain, korporasi, atau negara yang semestinya diperoleh" (Widjoyanto dkk. [ed.], 2010: 18).

Bentuk-bentuk korupsi sebagaimana definisi terakhir unsur-unsurnya dapat dijumpai dalam literatur hukum (fiqih) Islam seperti: ghu- 
lul(penggelapan), risywah (suap/sogok), khiyanat (tidak menepati janji), mukabarah dan ghasab (mengambil sesuatu dengan kekerasan dan paksaan), sariqah (pencurian), intikhab (merampas), ikhtilash (mencopet) dan aklu suht (makan hasil atau barang haram). Secara normatif perbuatan-perbuatan tersebut jelas dilarang dalam agama bahkan secara tegas dikenai sanksi sesuai hukum Islam. Sanksi tersebut berupa sanksi hukum dunia seperti dipotong tangan atau hukuman mati; sanksi sosial seperti dikucilkan masyarakat; dan sanksi moral seperti jika meninggal koruptor haram untuk disholatkan (Ibrahim dan Rukmana, 2010: 819-822).

Kejahatan korupsi dalam Peraturan Hukum Positif dikategorikan sebagai tindak pidana. Paradigma hukum positif melihat, "korupsi adalah tingkah laku yang menguntungkan kepentingan diri sendiri dengan merugikan orang lain, oleh para pejabat pemerintah yang langsung melanggar batas-batas hukum atas tingkah laku tersebut; sedangkan menurut norma-norma pemerintah dapat dianggap korupsi apabila hukum dilanggar atau tidak dalam bisnis tindakan tersebut adalah tercela" (Lubis dan Scott, 1993: 19). Pandangan korupsi dalam hal ini masih ambivalen yaitu hanya disebut dapat dihukum serta sebagai perbuatan tercela.

Selain kata korupsi, dikenal juga istilah turunan seperti kolusi dan nepotisme (KKN). Kolusi (collusion) dalam teori hukum adalah pemufakatan atau kerjasama secara melawan hukum atau penyelenggara negara atau antara penyelenggara negara dan pihak lain yang merugikan orang lain, masyarakat dan atau negara; nepotisme (nepotism) adalah setiap perbuatan penyelenggara negara secara melawan hukum yang menguntungkan kepentingan keluarganya dan atau kroninya di atas kepentingan masyarakat, bangsa dan negara. Paradigma deontologis ini menurut Gie (2004: 1) berusaha untuk mereduksi pemikiran para ekonom atau pebisnis neoklasik yang mengetahui bahwa "setiap orang bertindak sesuai moral, sepanjang hal itu masuk akal dari segi ekonomi."

Korupsi dalam konteks politik praktis kerap dikaitkan dengan penyalahgunaan suatu jabatan, wewenang atau kekuasaan dalam pe- 
merintahan. Korupsi dengan demikian sangat dekat sekali dengan 'kekuasaan'. Jacob Van Klaveren mengatakan bahwa seorang pengabdi negara (pegawai negeri) yang berjiwa korup menganggap kantor atau instansinya sebagai perusahaan dagang, sehingga dalam pekerjaannya akan diusahakan pendapatannya semaksimal mungkin (Nurdjana, 2010: 16). Alkostar (2008: 34-35) berpendapat bahwa korupsi dalam politik (pemerintahan) mempunyai arti sempit dan luas. Korupsi dalam arti sempit, merujuk pada tindakan yang dilakukan pejabat publik yang tidak jujur dan ilegal, contoh yang jelas adalah menerima suap. Korupsi dalam arti luas, meliputi tindakan pejabat publik yang meskipun tidak melanggar hukum, tetapi dalam sistem pemerintahan demokratis tindakan tersebut mencederai integritas.

Transparency International Indonesia (TII) memberikan definisi tentang korupsi sebagai perbuatan "menyalahgunakan kekuasaan dan kepercayaan publik untuk kepentingan pribadi" (Jeremy, 2003: 17). Unsur-unsurnya yaitu: (a) menyalahgunakan kekuasaan; (b) kekuasaan yang dipercayakan (baik di sektor publik maupun di sektor swasta) memiliki akses bisnis atau keuntungan materi; (c) keuntungan pribadi (tidak selalu berarti hanya untuk pribadi orang yang menyalahgunakan kekuasaan, tetapi juga anggota keluarga dan teman-temannya).

Korupsi dari sudut pandang ekonomi dikategorikan sebagai bentuk Commercial Crime, yaitu bentuk kejahatan-kejahatan serius yang implikasinya berhubungan dengan ekonomi, keuangan, dan perdagangan (Parwadi, 2010: 15). Korupsi dalam ilmu akuntansi merupakan bagian dari kecurangan atau penggelapan (fraud). Secara umum kecurangan berkaitan dengan beberapa hal: ketidakjujuran (dishonesty), penipuan (deceit), pelanggaran kepercayaan (breach of trust), pencurian (theft), maksud berbuat salah (intention to do wrong), dan rencana mendapatkan manfaat atau keuntungan dengan merugikan pihak lain (Suradi, 2006: 2).

Alatas, seorang pakar sosiologi korupsi (1987: 11) berpendapat, "Seperti halnya dengan semua gejala sosial yang rumit, korupsi tidak dapat dirumuskan dalam satu kalimat saja. Hal yang mungkin ialah membuat gambaran yang masuk akal mengenai gejala tersebut agar 
manusia dapat memisahkannya dari gejala lain yang bukan korupsi. Corruption is the abuse of trust in the interest of private gain."

Alatas memberikan tiga tipe fenomena yang tercakup dalam istilah korupsi: penyuapan (bribery), pemerasan (extortion), dan nepotisme (nepotism). Pada intinya korupsi ialah perbuatan yang menempatkan kepentingan-kepentingan publik di bawah tujuan-tujuan privat dengan pelanggaran norma-norma tugas dan kesejahteraan, yang dibarengi dengan keserbarahasiaan, pengkhianatan, penipuan, dan pengabaian yang kejam atas setiap konsekuensi yang diderita oleh publik (1987: 12). Alatas juga menegaskan untuk membedakan antara korupsi dan perilaku kriminal, antara korupsi dan mal-administrasi atau mismanajemen dengan memberikan ciri-ciri korupsi sebagai berikut:

1. Korupsi senantiasa melibatkan lebih dari satu orang. Hal ini tidak sama dengan kasus pencurian, misalnya penipuan. Seorang operator yang terasing yang korup sesungguhnya tidak ada, dan kasuskasus demikian biasanya termasuk dalam pengertian penggelapan (fraud).

2. Korupsi pada umumnya melibatkan keserbarahasiaan, kecuali di mana ia telah begitu merajalela dan mengakar sehingga individuindividu yang berkuasa atau mereka yang berada dalam lindungannya tidak tergoda untuk menyembunyikan perbuatan mereka namun di sini motif korupsi tetap dijaga kerahasiaannya.

3. Korupsi melibatkan elemen kewajiban dan keuntungan timbal balik yang tidaklah senantiasa berupa uang.

4. Mereka yang mempraktikkan cara-cara korupsi biasanya berusaha untuk menyelubungi perbuatannya dengan berlindung di balik pembenaran hukum.

5. Mereka yang terlibat korupsi adalah mereka yang menginginkan keputusan-keputusan yang tegas dan mereka yang mampu untuk mempengaruhi keputusan-keputusan itu.

6. Setiap tindakan korupsi mengandung penipuan, biasanya pada badan publik atau masyarakat umum.

7. Setiap bentuk korupsi adalah suatu penghkianatan kepercayaan. 
8. Setiap bentuk korupsi melibatkan fungsi ganda yang kontradikitif dari mereka yang melakukan tindakan itu.

9. Suatu perbuatan korupsi melanggar norma-norma tugas dan pertanggungjawaban dalam tatanan masyarakat. Ia didasarkan atas niat kesengajaan untuk menempatkan kepentingan umum di bawah kepentingan khusus (Alatas, 1987: 13-14).

Pengertian korupsi yang secara moral dan praktis mengandung unsur-unsur pokok dari korupsi adalah sebagaimana pengertian yang dikemukakan Nurdjana berikut ini:

"Korupsi diartikan sebagai suatu tingkah laku dan atau tindakan seseorang yang tidak mengikuti atau melanggar norma yang berlaku serta mengabaikan rasa kasih sayang dan tolong-menolong dalam kehidupan bernegara/bermasyarakat dengan mementingkan diri pribadi/keluarga/golongannya dan yang tidak mengikuti atau mengabaikan pengendalian diri sehingga kepentingan lahir dan batin atau jasmani dan rohaninya tidak seimbang, serasi dan selaras dengan mengutamakan kepentingan lahir berupa meletakkan nafsu dunia yang berlebihan sehingga merugikan keuangan/ kekayaan negara dan atau kepentingan masyarakat/negara baik secara langsung maupun tidak langsung" (Nurdjana, 2010: 19-20).

Beberapa pengertian korupsi di atas menunjukkan bahwa korupsi adalah suatu perbuatan yang 'melawan hukum, tidak wajar, dan tidak bermoral'. Substansi korupsi sebagai suatu kejahatan secara etis dipandang tidak baik dari sudut pandang manapun. Secara deontologis, korupsi bersifat 'jahat' dan 'merusak' sistem atau tatanan masyarakat. Secara teleologis, korupsi tidak banyak memberi manfaat bagi orang banyak dibanding kerugian yang ditimbulkannya. Korupsi sebagai suatu kejahatan moral secara praktis dapat terjadi di berbagai aspek kehidupan bermasyarakat (ekonomi, politik, hukum, pendidikan, sosial). Perbuatan korupsi seperi suap-menyuap (bribery), penyalahgunaaan wewenang atau kekuasaan, pemerasan (extortion), penggelapan atau 
kecurangan (fraud), dan lain-lain di antara tujuannya adalah untuk memperkaya diri sendiri dan atau kelompok, yang berakibat merusak tatanan sosial dan merugikan serta merampas hak orang banyak (publik atau negara).

\section{ESENSI KORUPSI SEBAGAI KEJAHATAN KEMANUSIAAN}

Manusia adalah makhluk ekonomi yang selalu berupaya memaksimalkan manfaat atas setiap aktivitas dengan biaya seminimal mungkin; dengan kata lain, dalam diri manusia sesungguhnya sudah ada benih atau kecenderungan untuk melakukan tindakan korupsi. Korupsi muncul sejak manusia mulai hidup berkelompok dan bermasyarakat, membangun relasi sosial untuk mempertahankan hidup, menciptakan norma-norma sosial demi suatu cita-cita seperti kebahagiaan, kesejahteraan, dan ketentraman hidup. Akan tetapi, masalah kemanusiaan mulai muncul ketika kejahatan oleh segelintir orang telah menciptakan ketidakadilan, kesengsaraan, dan penderitaan bagi sebagian yang lain. Nilai kebaikan dan kejahatan mulai dipertanyakan essensi dan keberadaannya di dalam diri manusia.

Hobbes dalam Campbell (1994: 85) pernah mengatakan, pada dasarnya manusia adalah makhluk individualis dan materialistis. Sebagai seorang positivis, Hobbes berpendapat bahwa kehidupan manusia adalah sebuah perjuangan terus-menerus untuk memuaskan hasrat. Kehidupan manusia adalah hasrat abadi dan tak kunjung padam untuk meraih kekuasaan demi kekuasaan, yang berhenti hanya dalam kematian. Baginya masyarakat adalah sebuah bangunan buatan yang didukung bersama dengan sebuah campuran kepentingan diri rasional, kekerasan, ancaman, dan penipuan. Manusia bermasyarakat disebabkan oleh hasrat ingin kuasa-menguasai satu sama lain, masyarakat adalah buatan manusia untuk mengatasi rasa takut dalam dirinya terhadap kesengsaraan dan kekecewaan.

Pendapat Hobbes di atas tidak berarti menegasikan adanya potensi kebaikan dalam diri manusia. Hidayat (2009: 802) menjelaskan, sebetulnya dalam diri manusia terdapat empat strata kejiwaan yang sangat mempengaruhi orientasi hidup: (1) Jiwa Nabati (vegetability) yaitu 
bersifat fisikal seperti aktivitas makan, minum, dan tumbuh.; (2) Jiwa Hewani (animality), yaitu jiwa yang selain bersifat nabati juga terdapat nafsu dan naluri untuk saling menerkam dan menghancurkan yang lain ketika dirinya merasa terancam. Uniknya, jika muncul nafsu atau keinginan, ia akan mendekat dan mengejarnya, tetapi kalau takut dan merasa terancam akan lari menjauhinya (fight or flight); (3) Jiwa Insani (humanity), ialah sumber dan poros utama kualitas kemanusiaan. Berbeda dengan jiwa nabati dan hewani yang mengandalkan insting, jiwa insani mempunyai daya refleksi, kesadaran moral, kreativitas, penghayatan seni, rasa humor, dan nalar sehat.

Hidayat mengatakan seorang koruptor sesungguhnya seorang yang hanya berasyik diri pada kehidupan level hewani, kualitas dan makna hidupnya dangkal sebab kebahagiaanya hanya disandarkan pada pemenuhan yang bersifat konsumtif semata. Selanjutnya ia berpendapat:

“Kalau seseorang korupsi hanya untuk memanjakan nafsu nabati dan hewani maka sungguh rendah orientasi hidupnya, kecuali korupsinya orang miskin dan bodoh semata untuk bertahan hidup, bisa jadi yang dosa bukannya yang korup melainkan orang kaya yang tidak membayar pajak dan pelit berzakat serta bersedekah. Di sini negara ikut berdosa telah ikut memelihara kemiskinan dan kebodohan sehingga seseorang terpaksa korupsi atau pun mencuri" (Hidayat, 2009: 803).

Oleh sebab itu menurut Hidayat, jiwa insani sangat dibutuhkan untuk mengemban amanat pendidikan dan pesan agama; bahwa dengan bekal nalar sehat, manusia hendaknya mampu membedakan dan membuat kalkulasi untung-rugi antara yang baik dan buruk, benar dan salah, dan agar manusia bisa mengendalikan jiwa nabati dan jiwa hewaninya. Manusia telah dianugerahi oleh Tuhan dengan dorongan kreativitas dan refleksivitas untuk mampu keluar dari hegemoni dan rutinitas perilaku instinctive lalu naik ke jenjang kesadaran rasional dan pilihan moral berdasarkan kemerdekaan yang dimilikinya (Hidayat, 
2009: 806); dengan kata lain, manusia memiliki tanggung jawab moral karena kesadaran dan pilihan bebasnya.

Pandangan agama sesungguhnya mengutuk keras atas tindakan korupsi. Tindakan koruptif di dalam ajaran agama Kristen adalah tindakan orang yang tidak memiliki kasih sayang. Korupsi dalam perspektif ajaran Islam adalah termasuk perbuatan fasad atau perbuatan yang merusak tatanan kehidupan. Pengertian fasad sendiri dapat diterjemahkan sebagai segala perbuatan yang menyebabkan hancurnya kemaslahatan dan kemanfaatan hidup, seperti membuat teror yang menyebabkan orang takut, membunuh, melukai, mengambil atau merampas hak orang lain. Pelakunya dikategorikan melakukan jinayah kubro (dosa besar) dan harus dikenai sanksi dibunuh, disalib atau dipotong tangan dan kakinya dengan cara menyilang (tangan kanan dengan kaki kiri atau tangan kiri dengan kaki kanan) atau diusir (Widoyanto dkk. [ed.], 2010: 135-136).

Korupsi dalam konteks ajaran Islam adalah tindakan yang bertentangan dengan prinsip keadilan (al-'adalah), akuntabilitas (al-amanah), dan tanggung jawab. Korupsi dengan segala dampak negatifnya yang menimbulkan berbagai distorsi terhadap kehidupan negara dan masyarakat dapat dikategorikan termasuk perbuatan fasad, kerusakan di muka bumi, yang sekali-kali amat dikutuk Allah SWT (Semma, 2008: 32-33).

Seorang koruptor pada dasarnya telah merusak kebutuhan dasar manusia lainnya, memporakporandakan dan mengabaikan normanorma essensial sebagai manusia. Berbagai pola kejahatan berdimensi baru (new dimention crime) seperti perbuatan korupsi dengan cara sindikat dan mafia kejahatan internasional melalui crime a business, organized crime, white collar crime, bank crime, monopoly oligopoly dan manipulation crime (Nurdjana, 2010: 43) telah menguras, merugikan sumber daya kekayaan negara skala besar yang puncaknya merusak tatanan masyarakat secara multidimensional (pendidikan, politik, hukum, ekonomi, sosial, agama). Kejahatan korupsi dalam dimensi ini secara struktural telah mengikis nilai-nilai moralitas kemanusiaan secara universal. 
Hal-hal yang manusiawi belum tentu berperikemanusiaan, dalam arti korupsi bisa saja disebut sebagai tindakan yang manusiawi seseorang yang mencari cara untuk memenuhi hasrat kebutuhan dasar, keinginan, dan kebahagiaan hidup. Akan tetapi, korupsi tidak sekedar dorongan-dorongan manusiawi saja, korupsi tidak bebas nilai sebab ia menyangkut moralitas seseorang. Korupsi adalah tindakan merusak, merugikan manusia dan lingkungan tempat manusia hidup. Oleh karena itu, korupsi adalah 'jahat' karena secara struktural menciptakan penderitaan bagi orang lain, korupsi merupakan extra ordinary crime.

Manusia diciptakan adalah untuk mengemban tugas sebagai individu dan sebagai makhluk sosial. Secara personal manusia bertanggung jawab terhadap pencipta-Nya, dan secara sosial manusia bertanggung jawab terhadap sesamanya. Filsuf muslim, Fazlur Rahman, berpendapat, hakikat hidup manusia adalah perjuangan moral yang tidak berkesudahan. Di dalam perjuangan ini, Allah berpihak pada manusia asalkan melakukan usaha-usaha yang diperlukan, karenanya di antara ciptaan Tuhan manusia memiliki posisi yang unik. Manusia diberi kebebasan berkehendak agar dapat menyempurnakan missinya sebagai khalifah Allah di muka bumi. Misi inilah, perjuangan untuk menciptakan sebuah tata sosial yang bermoral di atas dunia, yang dikatakan al-Qur'an sebagai amanah (Rahman, 1980:27).

Rahman (1980: 30) mengatakan, "Jika manusia sekali melakukan kebaikan atau kejahatan maka kesempataannya untuk mengulangi perbuatan yang serupa semakin bertambah dan untuk melakukan perbuatan yang berlawanan semakin berkurang bahkan untuk sekedar memikirkannya sekalipun"; dengan kata lain, apabila manusia melakukan kejahatan maka hati dan matanya akan 'tertutup'. Betapapun kuatnya pengaruh tindakan-tindakan kejahatan (korupsi) yang disebabkan kebiasaan psikologis, menurut Rahman tidak boleh dipandang sebagai determinan-determinan yang mutlak, karena bagi tingkah laku manusia tidak ada keterlanjuran yang tidak dapat diperbaiki.

Kelemahan manusia yang paling dasar dan yang menyebabkannya berlaku jahat adalah 'kepicikan' (dha'f) dan 'kesempitan pikiran' (qathr); karena kepicikan itulah manusia suka terburu-buru nafsu, pa- 
nik, dan tidak mengetahui akibat jangka panjang dari reaksi-reaksi yang dilakukannya; karena terburu nafsu inilah manusia menjadi sombong atau putus asa. Menurut Rahman, manusia telah terjebak dalam dua kutub ekstrim yang menjadikannya selalu goyah. Dua kutub tersebut adalah kesombongan dan keputusasaan.

Oleh karena manusia adalah makhluk yang goyah maka dibutuhkan energi moral yang dapat menyeimbangkan dua kutub ekstrim tersebut yaitu taqwa; yang berarti melindungi diri dari akibat-akibat perbuatan sendiri yang buruk dan jahat. Caranya adalah menghindari dari kesempitan akal dan kepicikannya sendiri. Oleh sebab itu, ada tiga macam pengetahuan yang penting bagi manusia yaitu, pengetahuan mengenai alam, sejarah dan dirinya sendiri (Rahman, 1980: 51).

Konsep taqwa hanya memiliki arti dalam konteks sosial. Tujuan al-Qur'an adalah menegakkan sebuah tata cara masyarakat yang adil dan egalitarian. Sehubungan dengan keadilan yang merata, al-Qur'an menetapkan prinsip bahwa "kekayaan tidak boleh berputar di kalangan orang-orang kaya saja” (59:7). Al-Qur'an juga melarang keras kegiatan persekongkolan-persekongkolan rahasia (najwa) yang bertujuan jahat dan aniaya (58:11-14); seperti halnya korupsi, kolusi, dan nepotisme dilarang karena merupakan perbuatan yang bertujuan jahat.

Pada dasarnya kekayaan dan usaha untuk mencari kekayaan adalah bukan hal yang buruk. Hal yang terpenting adalah bagaimana manusia memperoleh kekayaannya dan bagaimana ia mempergunakan kekayaannya (Rahman, 1980: 85). Manusia perlu memperhatikan cara yang 'baik' dan 'benar' secara moral dalam hal mendapatkan kekayaan untuk tujuan yang baik pula; baik itu untuk penghidupan (ma'isyah), kesenangan, dan seterusnya yang dianggap baik. Satu pandangan dari etika situasi disebutkan "akibat yang baik harus didahulukan dalam mempertimbangkan tingkah laku" (Titus dkk, 1984: 162). Akan tetapi, dalam konteks \kejahatan korupsi, cara (sarana) dan niat (motif) yang baik perlu didahulukan dari pada akibat (hasil) yang baik tetapi cara buruk. Alasannya, meminjam dari pendapat Giddens, bahwa manusia tidak akan pernah mengetahui secara pasti akibat (hasil) dari tindakannya sendiri selain karena memproyeksikannya (1976: 160), maka ko- 
rupsi sepatutnya diproyeksikan sebagai tindakan yang berakibat buruk dan jahat karena cara dan niatnya yang tidak baik.

\section{DIMENSI STRUKTURAL KEJAHATAN KORUPSI DALAM BINGKAI TEORI STRUKTURASI}

Esensi korupsi merupakan kejahatan kemanusiaan. Hal ini dipahami karena manusia pada dasarnya adalah makhluk ekonomi yang selalu berupaya memaksimalkan manfaat atas setiap aktivitas dengan biaya seminimal mungkin yang dengan kata lain, dalam diri manusia sesungguhnya sudah ada benih atau kecenderungan untuk melakukan tindakan korupsi. Korupsi muncul sejak manusia mulai hidup berkelompok dan bermasyarakat, membangun relasi sosial untuk mempertahankan hidup, menciptakan norma-norma sosial demi suatu cita-cita seperti kebahagiaan, kesejahteraan, dan ketentraman hidup. Akan tetapi, masalah kemanusiaan mulai muncul ketika kejahatan oleh segelintir orang telah menciptakan ketidakadilan, kesengsaraan, dan penderitaan bagi sebagian yang lain. Nilai kebaikan dan kejahatan mulai dipertanyakan essensi dan keberadaannya di dalam diri manusia.

Hobbes dalam Campbell (1994: 85) mengatakan, pada dasarnya manusia adalah makhluk individualis dan materialistis. Kehidupan manusia adalah hasrat abadi dan tak kunjung padam untuk meraih kekuasaan demi kekuasaan, yang berhenti hanya dalam kematian. Baginya, masyarakat adalah sebuah bangunan buatan yang didukung bersama dengan sebuah campuran kepentingan diri rasional, kekerasan, ancaman, dan penipuan. Manusia bermasyarakat disebabkan oleh hasrat ingin kuasa-menguasai satu sama lain, masyarakat adalah buatan manusia untuk mengatasi rasa takut dalam dirinya terhadap kesengsaraan dan kekecewaan.

Sementara pendapat Hidayat (2009: 802) dijelaskan, sebetulnya dalam diri manusia terdapat empat strata kejiwaan yang sangat mempengaruhi orientasi hidup: (1) Jiwa Nabati (vegetability) yaitu bersifat fisikal seperti aktivitas makan, minum, dan tumbuh.; (2) Jiwa Hewani (animality), yaitu jiwa yang selain bersifat nabati juga terdapat nafsu dan naluri untuk saling menerkam dan menghancurkan yang lain keti- 
ka dirinya merasa terancam. Uniknya, jika muncul nafsu atau keinginan, ia akan mendekat dan mengejarnya, tetapi kalau takut dan merasa terancam akan lari menjauhinya (fight or flight); (3) Jiwa Insani (humanity), ialah sumber dan poros utama kualitas kemanusiaan. Berbeda dengan jiwa nabati dan hewani yang mengandalkan insting, jiwa insani mempunyai daya refleksi, kesadaran moral, kreativitas, penghayatan seni, rasa humor, dan nalar sehat. Seorang koruptor bagi Hidayat sesungguhnya seorang yang hanya berasyik diri pada kehidupan level hewani, kualitas dan makna hidupnya dangkal sebab kebahagiaanya hanya disandarkan pada pemenuhan yang bersifat konsumtif semata.

Korupsi sebagai kejahatan kemanusiaan merupakan perbuatan yang telah merusak kebutuhan dasar sesama manusia, memporakporandakan dan mengabaikan norma-norma esensial manusia universal. Hal-hal yang manusiawi belum tentu berperikemanusiaan, dalam arti korupsi bisa saja disebut sebagai tindakan yang manusiawi seseorang yang mencari cara untuk memenuhi hasrat kebutuhan dasar, keinginan, dan kebahagiaan hidup. Akan tetapi, korupsi tidak sekedar dorongan-dorongan manusiawi saja, korupsi tidak bebas nilai sebab ia menyangkut moralitas seseorang. Korupsi adalah tindakan merusak, merugikan manusia dan lingkungan tempat manusia hidup. Oleh karena itu, korupsi adalah 'jahat' karena secara struktural menciptakan penderitaan bagi orang lain. Korupsi dipandang sebagai kejahatan luar biasa (extra ordinary crime) sebagaimana dikatakan oleh PBB 7 Oktober di Wina.

Manusia diciptakan adalah untuk mengemban tugas sebagai individu dan sebagai makhluk sosial. Secara personal manusia bertanggung jawab terhadap pencipta-Nya, dan secara sosial manusia bertanggung jawab terhadap sesamanya. Hakikat hidup manusia adalah perjuangan moral yang tidak berkesudahan (Rahman, 1980: 27). Betapa pun kuatnya pengaruh tindakan-tindakan kejahatan (korupsi) yang disebabkan kebiasaan psikologis, menurut Rahman, tidak boleh dipandang sebagai determinan-determinan yang mutlak, karena bagi tingkah laku manusia tidak ada keterlanjuran yang tidak dapat diperbaiki. 
Giddens mengatakan (1984: xxviii), setiap manusia yang hidup dalam masyarakat sosial adalah human agent. Setiap tindakan manusia disadari atau tidak, disengaja atau pun tidak, tentu berpengaruh terhadap setiap peristiwa atau keadaan sekecil apa pun di sekelilingnya. Seorang agen adalah seorang yang memiliki daya intervensi dengan keadaan pemicu atas suatu peristiwa. Seorang agen terus dikelilingi oleh struktur dan dapat mereproduksi struktur itu kembali dalam beragam peristiwa. Seorang agen dapat menciptakan keadaan struktural dalam dunia sosialnya secara dialectic, diantaranya kejahatan yang berdimensi struktural melalui kemampuan refleksivitas dan rasionalisasi tindakan.

Korupsi merupakan bagian dari kejahatan struktural. Korupsi secara struktural menjadi penyebab pokok kemiskinan dan kekacauan sosial. Korupsi merupakan kejahatan yang multikompleks. Walaupun terkesan hanya terkait dengan persoalan harta benda, korupsi mempunyai karakter tersendiri. Korupsi tidak hanya melibatkan seseorang yang berkuasa, tetapi meliputi kejahatan yang langsung dilakukan oleh seseorang melalui kekuasaan yang diembannya. Korupsi lebih serius hanya sekedar suap atau sogok, tetapi meliputi kasus pemegang kekuasaan yang langsung mencuri harta publik melalui otoritas yang dimilikinya tanpa melibatkan orang lain yang berada di luar lingkar kekuasaan.

Secara struktural, hasrat korupsi berjalan di atas ego kognitif yang merupakan potensi dasar manusia sebagai mikro kosmos. Sebagai animal rasionale atau human agent, manusia senantiasa merasionalisasi kehidupannya untuk menjadi lebih masuk akal. Meskipun manusia bagian dari struktur mikro alam semesta, ia memiliki dimensi sosial yang sifat perkembangannya berbeda dengan struktur alam. Perkembangan alam semesta dalam ilmu-ilmu alam memiliki watak deterministic dan menghasilkan resiko yang jelas dan pasti (nature risk), sedangkan perkembangan dunia sosial berwatak dialectic dan terbuka (manufactured risk). Potensi alam bersifat determinant, teleologis dan menghasilkan resiko yang jelas atau dapat diukur. Sementara itu potensi manusia dan sejarah sosialnya adalah bersifat dialectic dan relatif 
menghasilkan resiko yang tidak pasti, dinamis, serta terbuka atas berbagai kemungkinan (Giddens, 1990: 154).

Kesadaran atau sensibilitas (kemampuan merasakan) kejahatan dalam kapasitas refleksif seorang agen ditentukan oleh barisan stimuli yang ada sekelilingnya yang disebut dengan gugusan struktur. Struktur adalah aturan-aturan (rules) dan sumberdaya (resources) yang merupakan pedoman atau prinsip praktik-praktik di berbagai ruangwaktu; dan merupakan 'hasil perulangan berbagai tindakan sosial' (reproduksi sosial). Aturan ini berbentuk skemata yang menjadi sarana terjadinya praktik sosial. Giddens menyebutkan tiga gugusan besar struktur yang dijadikan prinsip aturan dan sumberdaya oleh agenagen sosial. Pertama, struktur penandaan (signifikasi) yang menyangkut skemata simbolik, pemaknaan, penyebutan, dan wacana. Kedua, struktur penguasaan (dominasi) atas orang (politik) dan barang atau hal (ekonomi). Ketiga, struktur pembenaran (legitimasi) yang menyangkut skemata peraturan normatif yang terungkap dalam tata hukum atau tata moral (1976: 123-124).

Pemahaman korupsi sebagai kejahatan struktural tidak dapat dipisahkan dari pemahaman tindakan moral yang merupakan bentuk refleksif agen-agen sosial. Bentuk refleksivitas bergantung pada jangkauan pengetahuan agen-agen manusia. Refleksivitas hanya mungkin terwujud bila ada kesinambungan praktik-praktik yang 'sama' di sepanjang ruang dan waktu. Refleksivitas dipahami tidak hanya sebagai 'kesadaran diri' tetapi sebagai sifat arus kehidupan sosial yang sedang berlangsung yang senantiasa dimonitor. Refleksi agen saja tidak cukup, sebab setiap tindakan moral membutuhkan pertanggungjawaban maka di sini pentingnya institusionalisasi tanggung jawab dalam bentuk legitimasi hukum.

Korupsi menjadi kejahatan struktural bukan karena adanya struktur (sistem) sosial yang mengamini melainkan karena adanya hubungan dualitas (timbal balik) antara struktur dan agen. Struktur korupsi tidak berdiri otonom sebab struktur bukanlah aturan-aturan atau sumber daya yang bersifat mengekang agen. Sebagai makhluk potensial, agen dapat pula memberdayakan struktur tergantung 'modalitas' 
yang dimiliki agen. Terbentuknya struktur tidak dalam waktu pendek, tetapi melewati satuan waktu dengan tidak membatasi pada ruangruang tertentu.

Manusia bukanlah entitas atau benda mati yang tidak punya kuasa apa-apa. Korupsi merupakan perbuatan kejahatan yang dilakukan secara sadar (refleksif) dan bertanggung jawab. Kapasitas kesadaran refleksif meliputi cara terus-menerus dengan aliran kejadian seharihari dalam konteks tindakan sosial. Akan tetapi, refleksivitas menggerakkan hanya satu bagian dari tingkatan diskursif (ungkapan verbal). Apa yang agen ketahui tentang apa yang mereka lakukan dan mengapa mereka melakukan itu, pengetahuan mereka sebagai agen, jelas-jelas dibawa dalam kesadaran praktis. Kesadaran praktis terdiri atas semua hal yang aktor-aktor mengetahui secara diam-diam tanpa dapat memberi mereka pernyataan diskursif secara langsung.

Korupsi sebagai kejahatan struktural adalah berakar pada banality atau pembiasaan yang dilakukan oleh agen-agen sosial dalam memproduksi dan mereproduksi struktur-struktur korupsi. Pada kasus korupsi yang telah menjadi wabah epidemic atau endemic dalam masyarakat Indonesia misalnya adalah karena agen-agen korupsi tengah berada dalam kesadaran praktis dan kognitif (motif tak sadar) akibat tindakan-tindakan rekursif (berulang) dan berpola. Korupsi jenis ini melanda hampir setiap komponen birokrasi, mulai dari istana sampai kantor kelurahan, bahkan pada tingkat RW/RT. Korupsi ini terjadi di hampir semua lini kehidupan, mulai dari urusan kelahiran sampai kematian, bangun tidur sampai tertidur kembali. Korupsi menjadi suatu kewajaran dalam relasi-relasi kolektivitas, menjadi lingkaran setan yang terus bereproduksi menjadi korupsi berjamaah.

Kejahatan struktural korupsi bukan tidak mungkin merupakan problem kejahatan manusia modern di mana gugusan strukturnya berasal dari nilai-nilai modernitas, seperti kebebasan, sekularisme, individualisme, liberalisme, pragmatisme, yang menandai tempat bagi relasi-relasi sosial masyarakat. Menurut Giddens (1990: 36), manusia yang hidup dalam realitas kosmos modern akhir berjalan diatas logika 'percepatan' sehingga mengakibatkan orang tidak dapat berfikir panjang, mengambil jalan pintas, berfikir dan bertindak praktis. 
Konsekuensi modernitas dan globalisasi adalah sesuatu yang tidak bisa dihindari selama gugusan stuktur penopangnya masih eksis di muka bumi ini. Adanya perentangan atau pemadatan ruang waktu dalam skala global menunjukkan bahwa manusia tidak hanya mampu menciptakan sejarah tetapi juga menciptakan geografi waktu dan ruang. Mendunianya teknologi industri, transportasi, informasi, dan telekomunikasi pada saatnya membawa pengaruh keseimbangan lingkungan (alam) dan kepercayaan lokal. Konsekuensinya, segala nilainilai lokalitas (tradisi) dan relijiusitas (agama) yang dipercayai sebagai petunjuk moral dan jalan hidup kini 'tercabut' dari makna dasarnya akibat dapak globalisasi yang menjadi ciri modernitas akhir. Korupsi menjadi pilihan hidup.

Moralitas hanya menjadi tunggangan untuk melegitimasi kepentingan pribadi atau kelompok. Idealisme-idealisme utopis dalam logika 'percepatan' modernitas berbenturan dengan realitas-realitas semu yang berdampak pada cuaca batin manusia modern. Banyaknya pilihan moral yang ditawarkan oleh tradisi dan agama menjadi semu di tengah keadaan dunia sosial yang terus bertransformasi dengan cepat.

Berpijak pada konteks tranformasi tersebut, maka korupsi sebagai kejahatan moral menuntut adanya reformasi sistem-sistem moral dari institusi-institusi sosial yang ada di masyarakat seperti agama, hukum, politik, ekonomi, budaya, dan pendidikan. Persoalan-persoalan korupsi harus diintegrasikan dalam kebijakan politik negara-bangsa. Setiap gerakan politik dan sosial harus mempertahankan inti keadilan sosial, mencari suatu keseimbangan antara tanggung jawab individual dan kolektif dalam komunitas masyarakat, "meluasnya individualisme seharusnya disertai dengan perluasan kewajiban individual" (Giddens, 1998: 74-75).

Makna struktural kejahatan korupsi dalam konteks dunia global ialah bahwa korupsi memiliki sifat-sifat struktural kejahatan yang memiliki rentang ruang-waktu terluas dan dimensi-dimensi struktur (budaya, ekonomi, politik, hukum) yang saling kait mengkait. Tindakan kejahatan tersebut tidak terlepas dari jaringan tindakan produksi dan reproduksi struktur oleh agen, yang hadir dalam konteks kehadiran 
maupun ketidakhadiran, yang membentuk setting atas apa yang dikatakan dan apa yang dikerjakan satu sama lain dalam seluruh totalitas gejala (Giddens, 1984: Bab I).

Penempatan korupsi sebagai problem kejahatan struktural merupakan konsekuensi dari kosmologi modernitas yang tengah bergerak menjadi kekuatan semakin tidak terkendali akibat arus globalisasi. Giddens melihat modernitas menjadi semakin radikal dan tidak terkendali ini akibat tiga kondisi penting yang mengglobal dan saling berhubungan satu sama lain: "the separation (distanciation) of time and space, the development of disembedding mechanism, and the reflexive appropriation of knowledge" (1990:53).

Korupsi biasa diidentikkan dengan uang. 'Uang' dalam konsepsi Giddens, adalah bentuk dari mekanisme disembedding (keterlepasan) yang merupakan ciri kedua modernitas (1990: 23), dimana kondisi mekanisme disembedding turut 'mencabut' aktivitas sosial dari konteks lokalitasnya, diorganisasikan kembali dalam relasi-relasi sosial menembus batas jarak ruang-waktu. Dua bentuk mekanisme 'keterlepasan' secara intrinsik dalam perkembangan institusi-institusi sosial modern yaitu; kreasi tanda-tanda simbolik (symbolic tokens) dan pembangunan sistem-sistem ahli (expert system). Konsep uang secara tradisional adalah sebagai alat pertukaran (barter) namun pada perkembangannya tanda 'uang' menjadi simbol nilai dan komoditi (ekonomi uang). Uang dalam korupsi bukanlah tujuan esensiil tetapi hanya sebagai alat untuk mencapai kepentingan-kepentingan, sebab uang adalah produk dari mekanisme simbolik dari sistem abstrak.

Masyarakat modern adalah masyarakat yang ditandai oleh kegiatan mengambil resiko secara aktif. Konsep risk untuk era modern menggantikan berbagai konsep tentang nasib atau takdir Illahi pada era tradisi. Resiko adalah cara orang modern memahami masa depan yang kontingen dengan segala kalkulasi dan kepasrahan. Ketika kosmologi relijius atau alamiah masih kokoh, orang tidak perlu pusing memikirkan apa yang terjadi besok dan apa yang harus dilakukan. Masa depan sudah dikunci oleh tafsiran-tafsiran relijius. Kosmologi modern membiarkan sejarah berjalan tanpa jaminan apapun di masa 
depan. Masa depan sepenuhnya ditentukan oleh kalkulasi rasional manusiawi. Derasnya lalu lintas informasi menyurutkan peran tradisi yang bisa berdiri kukuh didera derasnya informasi itu dan yang tinggal adalah tradisi yang terus-menerus mengalami penemuan (invited tradition). Masyarakat kontemporer ditandai oleh Giddens sebagai detradisionalisasi. Moralitas relijius pun makin berubah cepat seiring logika percepatan modernitas. Korupsi dalam konteks ini, adalah cermin dari hilangnya kosmologi relijius bersama refleksivitas yang mengalami detradisionalisasi.

Upaya koruptor untuk menghindari tanggung jawab moral dapat dengan melegitimasi dan merasionalisasi tindakan 'jahat'nya secara personal. Sementara untuk menebus dosa dan rasa bersalah di hadapan publik, seorang koruptor yang anti-sosial berupaya mengambil simpati sosial dengan aktivitas sosial. Dosa korupsi dalam persepsi koruptor dapat dibersihkan misalnya, dengan banyak beramal, bersedekah, menyantuni anak yatim, membangun tempat ibadah, dan menjadi donator bagi kegiatan-kegiatan sosial lainnya. Ini menandakan bahwa moral korupsi yang secara ontologis menegasikan prinsip kesejahteraan dan keadilan sosial, secara kontradiktif dihadapkan dengan realitas tindakan yang dapat menciptakan keadaan itu kembali.

Eksistensi kepercayaan relijius (supranatural) yang menjadi sumber kegelisahan dan ketidakamanan psikologis bagi koruptor di era dominasi teknologi dan sains tergantikan dengan adanya rasa aman ontologis (ontological security). Ontological security adalah istilah Giddens yang digunakan untuk merujuk kepada situasi atau kesadaran atau keyakinan eksistensial bahwa dunia tempat manusia hidup ini secara moral dan sosial teratur dan bumi ini aman (1984).

Seorang koruptor mungkin menyadari bahwa ada resiko sosial dan hukum yang akan diterimanya apabila melakukan kecurangan dan penyalahgunaan wewenang, tetapi rasa ini ditenggelamkannya dalam-dalam bersama ego kognitif yang mendasarinya. Hal yang nampak bagi koruptor adalah bagaimana mencari cara untuk mempertahankan eksistensi diri, lalu merasionalisasi tujuannya tersebut supaya nampak benar dan masuk akal. Dicarilah alat-alat pembenaran yang 
bisa melindunginya dari jeratan hukum. Seorang koruptor tidak perlu khawatir karena ada expert system/abstract system yang membantunya dalam segala hal; ada teknologi komunikasi dan informasi (media massa) yang bisa dimainkannya untuk membangun opini, melemparkan wacana bahwa dirinya bersih dan tidak korup; ada teknologi yang dapat menghapus data kecurangannya di dunia maya dengan sekali pencet; atau didapat bekerjasama dengan sistem perbankan internasional yang bisa mengamankan harta korupsinya sambil melarikan diri ke negara lain yang bisa memberinya rasa aman. Bahkan ada pula ayatayat teologis-relijius yang bisa ditafsirkan secara semena-mena untuk melegitimasi perbuatan jahatnya di saat kemampuan abstract system tidak lagi memberinya rasa aman secara ontologis. Hal inilah yang menyebabkan mental korupsi sulit disembuhkan disaat korupsi sudah menjadi pilihan hidup untuk beraktualisasi diri. Korupsi dilakukan berdasarkan keputusan personal bahkan dengan penuh rasa tanggung jawab oleh agen-agennya.

Teori strukturasi sangat relevan untuk mengurai benang kusut fenomena korupsi yang ada di Indonesia yang dalam hal ini dapat dilakukan melalui tiga tahap: (1) Mengurai bingkai interpretasi masyarakat terhadap makna korupsi; (2) Mengidentifikasi sumber dayasumber daya alokatif dan otoritatif yang turut memberdayakan dan menguatkan praktik korupsi; (3) Melihat unsur-unsur yang menjadi alat pembenaran (justifikasi) bagi alibi-alibi hukum positif maupun normatif (sosial-agama).

Pada aspek sosial-politik, ekonomi, dan hukum dapat disimpulkan bahwa korupsi di Indonesia sulit diberantas ialah karena beberapa hal: (1) Adanya distorsi makna perilaku politik dimana masalah moral direduksi menjadi masalah manajemen politik; (2) Adanya impunity (tiadanya sanksi hukum) dimana proses hukum berbalik menjadi alat pembersihan diri dan sarana rehabilitasi koruptor; dan (3) Adanya intervensi kekuasaan di dalam lembaga peradilan yang dimungkinkan karena fasilitas kekuasaan seperti pejabat yang ditunjuk, sumberdaya ekonomi, dan dukungan politik (kekuatan tawar). 


\section{SIMPULAN}

Kejahatan korupsi merupakan kejahatan kemanusiaan atau kejahatan moral yang akar dan tanggung jawabnya kembali kepada potensi dasar manusia. Potensi ini secara konstitutif berasal dari kekuatankekuatan struktural. Struktural diartikan sebagai sesuatu yang mengekang (constraining) dan memberdayakan (enabling). Akarnya adalah berasal dari potensi alam (nature risk) dan potensi manusia (manufactured risk) sebagai human agent. Potensi alam bersifat determinant, teleologis dan menghasilkan resiko yang jelas atau dapat diukur, sedangkan potensi manusia adalah bersifat dialectic dan relatif menghasilkan resiko yang tidak pasti, lebih dinamis, serta terbuka atas berbagai kemungkinan.

Korupsi sebagai kejahatan struktural, dari waktu ke waktu memiliki pola dan stuktur yang sama karena adanya potensi-potensi yang terus dirasionalisasi oleh agen-agennya. Struktur dasar atau potency yang dijadikan landasan untuk berbuat korupsi terdiri dari: (1) Struktur signifikasi; meliputi prinsip pemaknaan (mode wacana) yang dijadikan bingkai interpretasi terhadap suatu tindakan yang disebut 'korup' dan 'jahat'; (2) Struktur dominasi; meliputi sumber daya-sumber daya yang dapat dimobilisasi dan direproduksi dalam konteks penguasaan yang bersifat alokatif (materiil/ekonomi) dan otoritatif (orang/politik) dalam korupsi; dan (3) Struktur legitimasi; ialah prinsip regulasi normatif (institusi legal) yang dapat dijadikan alibi dan payung hukum bagi tindakan korupsi.

Sebagaimana potensi baik dan buruk, korupsi merupakan potensi manusia yang bisa muncul kapan saja dalam kehidupan bermasyarakat dan berkelompok. Namun korupsi adalah musuh bagi kebaikan dan keutamaan. Ia adalah hasrat dan 'ego kognitif' yang sanggup merasionalkan segala cara demi memenuhi tujuan terpendam dari 'motif tak sadar'. Akarnya adalah nafsu serakah serta mementingkan sesuatu yang bersifat materiil dan instrumental.

Reproduksi dan transformasi kejahatan korupsi dalam sejarah masyarakat disebabkan oleh tiga kondisi struktural seperti: (1) Peren- 
tangan, pemisahan, dan pemadatan ruang-waktu; (2) Pencabutan nilai lokalitas dari konteksnya, dan (3) Mekanisme refleksivitas pengetahuan agen manusia. Melalui rasio yang dimiliki, manusia menjadi makhluk kreatif dan refleksif dalam sosialnya sehingga sanggup merasionalisasi kehidupannya menjadi lebih efektif dan efisien. Sebagai human agent, manusia sanggup memobilisasi struktur dasarnya dalam suatu gugusan struktur (sistem) seperti tata nilai (signifikasi), tata kuasa (dominasi) dan tata hukum (legitimasi).

Korupsi mengakar dan merajalela dalam masyarakat karena adanya kondisi struktural yang unsur-unsurnya teruserreproduksi oleh tindakan-tindakan praktis dan banality; yaitu pembiaran-pembiaran dan pembiasaan-pembiasaan baik oleh individu maupun sosial seperti praktik-praktik ketidakjujuran, dominasi kekuasaan, alibi-alibi hukum, sikap pasrah terhadap ketidakadilan, serta banalitas-banalitas lainnya yang prinsipnya turut mengamini dan memaklumi praktikpraktik korupsi.

Batas antara korupsi dan asas manfaat oleh pribadi atau suatu kelompok untuk mencapai tujuan tertentu sangatlah tipis garisnya. Ujung dari perdebatannya adalah masalah etika; apakah suatu perbuatan dikatakan bermoral karena caranya, atau tujuannya (motif/niat), atau hasilnya? Ketiga hal ini senantiasa dirasionalisasi oleh agen-agen koruptor secara sadar untuk menutupi perasaan bersalah berdasarkan ontological security; yaitu suatu keyakinan atau rasa aman terhadap keteraturan moral dan sosial seperti eksistensi, identitas, kemapanan, pertahanan hidup (surviving) dan lain-lain.

Korupsi sebagai kejahatan yang berdimensi struktural secara global ditopang oleh kondisi-kondisi modernitas yang gugusan strukturnya bersifat timeless, spaceless, virtual, constraining, dan enabling. Proses strukturasinya, melewati tiga dimensi; distanciation, disembedding, dan reflexivity. Untuk mengurai benang kusut dari strukturasi korupsi yang ada di Indonesia dapat dilakukan dengan tiga tahap: (1) Mengurai bingkai interpretasi masyarakat terhadap makna korupsi; (2) Mengidentifikasi sumberdaya-sumberdaya alokatif dan otoritatif yang turut memberdayakan dan menguatkan praktik korupsi; (3) Melihat unsur- 
unsur yang menjadi alat pembenaran (justifikasi) bagi alibi-alibi hukum positif maupun normatif (sosial-agama).

Secara kasat mata, uang menjadi tujuan akhir dari korupsi namun pada dasarnya uang hanyalah alat dari abstract system yang sifatnya disembedding (taktersimpan). Uang sanggup 'mencabut' lokalitas maknanya dari sekedar komoditi (alat tukar) menjadi nilai sesuatu; seperti uang adalah modal, jabatan, kesempatan, kekuasaan, kemapanan, dan lain-lain. Signifikasi tersebut melahirkan praktik korupsi seperti penyalahgunaan wewenang/jabatan, komersialisasi layanan publik, pemerasan, kecurangan, dan jenis-jenis korupsi lainnya.

Korupsi sebagai kejahatan struktural bukanlah kejahatan yang anonim (tanpa wajah) melainkan struktur dan agensinya dapat disendirikan dengan memperhatikan resiko-resiko masing-masing tindakan. Dampak struktural korupsi merupakan bagian dari manufactured risk (resiko yang dibuat) oleh manusia sendiri atas kepercayaannya terhadap abstract system/expert system. Penaggulangan korupsi seharusnya dibarengi dengan pembersihan perbuatan-perbuatan ilegal seperti illegal logging, fishing, trading, dan lainnya yang kesemuanya membutuhkan sistem ahli yang bermoral. Gerakan-gerakan moral seperti gerakan antikorupsi sebagai wujud kontrol sosial-politik idealnya berkolaborasi dengan gerakan-gerakan kemanusiaan lainnya yang secara riil berkontribusi bagi terciptanya solidaritas masyarakat untuk saling mengurangi beban kemiskinan, ketidakadilan yang menjadi akar tindakan-tindakan koruptif.

\section{DAFTAR PUSTAKA}

Alatas, Syed Hussein, 1981, Sosiologi Korupsi terj. Al Ghozie Usman, LP3ES, Jakarta.

1987, Korupsi (Sifat, Sebab, dan Fungsi), terj. Nirwanto, LP3ES, Jakarta.

Ali, As'ad Said, 2009, Negara Pancasila; Jalan Kemaslahatan Berbangsa, LP3ES, Jakarta.

Alkostar, Artidjo, 2008, Korupsi Politik di Negara Modern, UII Press, Yogyakarta. 
Arendt, Hannah, 1993, Asal-usul Totaliterisme, terj. A. Agus Nugroho, Yayasan Obor Indonesia, Jakarta.

Bria, Emanuel, 2008, Jika Ada Tuhan Mengapa ada Kejahatan; Percikan Filsafat Whitehead, Kanisius, Yogyakarta.

Campbell, Tom, 1994, Seven Theories of Human Society (Tujuh Teori Sosial; Sketsa, Penilaian, Perbandingan, terj. Budi Hardiman), Kanisius, Yogyakarta.

Driyarkara, 2000, Menelusuri Gagasan Anthony Giddens, Majalah Filsafat STF Driyarkara, Jakarta.

Echols, John M. dan Shadily, Hassan, 1996, Kamus Inggris-Indonesia, PT Gramedia, Cetakan ke-28, Jakarta.

Gie, Kwik Kian, 2004, Korupsi, Kolusi dan Nepotisme Akar Masalah Semua Permasalahan Bangsa, Kompas, 4 Agustus 2004.

Giddens, Anthony, 1976, New Rules of Sosiological Method; A Positive Critique of Interpretative Sociologies, Hutchinson, London. 1979, Central Problems in Social Theory, Mcmillan, London.

1981, Contemporary Critique of Historical Materialism, Macmillan, London. 1984, The Constitution of Society, Polity Press, Cambridge.

1985, The Nation State and Violence, Polity Press, Cambridge.

and Turner, Jonathan (ed.), 1987, Social Theory Today, Polity Press, Cambridge.

Cambridge. 1990, The Consequences of Modernity, Polity Press, 1991, Modernity and Self-Identity, Polity Press, Cambridge. 1998a, The Third Way; The Renewal of Social Democracy, Polity Press, Cambridge. 1998b, Conversations with Anthony Giddens, Polity Press, Cambridge. 1999, Runaway World: How Globalization is Reshaping Our Lives, Provile Books. 
Hidayat, Komaruddin, 2009, "Psikologi Korupsi" dalam Wijayanto \& R. Zachrie (ed.), Korupsi Mengorupsi Indonesia; Sebab, Akibat, dan Prospek Pemberantasan, Kompas Gramedia, Jakarta.

Hoefnagels, G. Peter, 1984, Philosophy of Crime (Kejahatan dalam Ancangan Filsafat), terj. R. Soedjono Dirdjosisworo, Penerbit Alumni, Bandung.

Jeremy, Pope, 2003, Strategi Memberantas Korupsi, Elemen Sistem Integritas Nasional, Yayasan Obor Indonesia, Jakarta.

Klitgaard, Robert, 1988, Controlling Corruption, University of California Press, California.

Klitgaard, Robert, 1999, Menyingkap KKN di Indonesia, Aditya Media, Yogyakarta.

2005, Membasmi Korupsi, terj. Hermojo, Yayasan Obor Indonesia, Yogyakarta.

Lubis, M dan Scott, J.C., 1993, Korupsi Politik, Yayasan Obor Indonesia, Jakarta.

Nurdjana, IGM, 2010, Sistem Hukum Pidana dan Bahaya Laten Korupsi (Perspektif Tegaknya Keadilan Melawan Mafia Hukum), Pustaka Pelajar, Yogyakarta.

Parwadi, Redatin, 2010, Koruptologi, Kanisius, Yogyakarta.

Poerwadarminta, W.J.S., 1984, Kamus Umum Bahasa Indonesia, Balai Pustaka, Jakarta.

Priyono, B. Herry, 1999, "Anthony Giddens dan Teori Strukturasi" dalam Basis, No. 09-10, Tahun ke-48, September-Oktober, Yogyakarta.

Rahman, Fazlur, 1995, Major Theme of the Qur'an, (Tema Pokok al-Qur'an), terj. Anas Mahyuddin, Penerbit Pustaka, Bandung.

Ross, Daniel dalam Beilharz, Peter, 2003, Teori-teori Sosial, terj. Sigit Jatmiko, Cetakan ke-2, Pustaka Pelajar, Yogyakarta.

Semma, Mansyur, 2008, Negara dan Korupsi; Pemikiran Mochtar Lubis Atas Negara, Manusia, Indonesia, dan Perilaku Politik, Yayasan Obor Indonesia, Jakarta.

Singgih, 2008, Dunia pun Memerangi Korupsi (Beberapa Catatan Internasional Anti Corruption Conference I-X dan Dokumen PBB tentang 
Pemberantasan Korupsi), Pusat Studi Hukum Bisnis Universitas Pelita Harapan, Jakarta.

Siswanto, Joko, 2008, Ontologi Kejahatan (Relevansinya bagi Kejahatan Korupsi di Indonesia), Disertasi Ilmu Filsafat, Universitas Gadjah Mada, Yogyakarta.

Suradi, 2006, Korupsi dalam Sektor Pemerintah dan Swasta (Mengurai Pengertian Korupsi; Pendeteksian, Pencegahannya, dan Etika Bisnis), Gava Media, Yogyakarta.

Syamsuddin, Mukhtasar, 2011, Kejahatan Korupsi; ditinjau dari Ethos Kerja Manusia Bugis-Makassar, Makalah diskusi LAFINUS, 24 Juni 2011, Yogyakarta.

Widjoyanto, Bambang dkk. (ed.), 2010, Koruptor Itu Kafir; Telaah Fiqih Korupsi Muhammadiyah dan Nahdlatul Ulama, PT Mizan Publika, Jakarta.

Wijayanto dan Zachrie, Ridwan (ed.), 2009, Korupsi Mengorupsi Indonesia; Sebab, Akibat, dan Prospek Pemberantasan, Kompas Gramedia, Jakarta.

\section{Sumber Internet :}

http://rezaantonius.multiply.com/journal/item/18, download 19/01/2011

http://id.wikipedia.org/wiki/AnthonyGiddens, download 19/01/2011

http://suaramerdeka.com/2008/09/04, download 10-05-2011

Kompas.com, 8 April 2010, download 12/01/2011

Vivanews, 8 Maret 2010, download 12/01/2011 